\title{
Knowledge, attitude and practices about pharmacovigilance and adverse drug reactions among dental research assistants in a Turkish hospital: a cross-sectional study
}

\author{
Bir Türk hastanesindeki diş araştırma asistanları arasında farmakovijilans ve advers \\ ilaç reaksiyonları hakkında bilgi, tutum ve uygulamalar: kesitsel bir çalışma
}

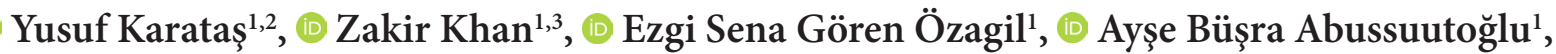 \\ D Aykut Pelit ${ }^{4}$, (ㄷ) Elif Figen Koçak ${ }^{5}$ \\ ${ }^{1}$ Çukurova University, School of Medicine, Department of Medical Pharmacology, Adana, Turkey \\ ${ }^{2}$ Cukurova University, Balcalı Hospital, Pharmacovigilance Specialist, Adana, Turkey \\ Quaid-i-Azam University, Department of Pharmacy, Islamabad, Pakistan \\ Çukurova University, School of Medicine, Department of Biophysics, Adana, Turkey \\ ${ }_{5}^{5}$ Çukurova University, School of Dentistry, Department of Prosthetic Dental Treatment, Adana, Turkey
}

Cite this article as / Bu makaleye atıf için: Karataş Y, Khan Z, Gören Özagil ES, Abussuutoğlu AB, Pelit P, Koçak EF. Knowledge, attitude and practices about pharmacovigilance and adverse drug reactions among dental research assistants in a Turkish hospital: a cross-sectional study. J Health Sci Med 2020;3(4): 367-371.

\begin{abstract}
Aim: This study was aimed to assess pharmacovigilance and adverse drug reactions knowledge, attitudes and practices of dental research assistants.

Material and Method: A cross-sectional survey was conducted in a teaching hospital at Cukurova University, Adana, Turkey, for one month. All the registered dental research assistants were invited to participate in the study. Data collection was carried out through the self-administered and validated questionnaire. The final data was analyzed by using SPSS version 21.0 (IBM, Armonk, NY, USA). Descriptive statistics such as frequencies and percentages have been determined. Results: The questionnaire was completed by invited participants with a response rate of $92.5 \%$. Male $(\mathrm{n}=30,60 \%)$ was more than female $(\mathrm{n}=20,40 \%)$ with an average age of $27.44(\mathrm{SD} \pm 2.32)$ years. None of the participants received pharmacovigilance training in the last 1 year. The majority of participants $(60 \%)$ were unable to define pharmacovigilance and only $20 \%(\mathrm{n}=10)$ of the dentists have correctly defined ADRs. The Most of respondents $(90 \%)$ recognize ADR reporting as a professional obligation and sixty percent $(n=30)$ perceived that the reporting of serious and unexpected ADRs are mandatory. The participants perceived that difficulties during filling of ADR forms, loss of timing and lack of information on pharmacovigilance are the main reason for the under-reporting of ADRs. Moreover, all dentists reported that they did not observe serious/severe ADRs, and $40 \%(n=20)$ reported not asking about ADR history while interacting with a patient for the first time during their practice. The participants had poor knowledge attitude and practice towards the pharmacovigilance and adverse drug reactions ( $\mathrm{P}$ value $<0.05)$.

Conclusion: The current study demonstrated a lack of awareness and knowledge of pharmacovigilance and ADR among dental research assistants. The inclusion of pharmacovigilance literature in the education program is mandatory and pre-and post-graduate training should be provided to dentists for rational practices.

Keywords: Pharmacovigilance, adverse drug reactions, dentists, knowledge, Turkey, hospital
\end{abstract}

\section{ÖZ}

Amaç: Bu çalışma, dental araştırma görevlilerinin farmakovijilans ve advers ilaç reaksiyonları (ADR) bilgilerini, tutumlarını ve uygulamalarını değerlendirmeyi amaçlamaktadır.

Gereç ve Yöntem: Bir ay süreyle Adana, Çukurova Üniversitesỉnde bir eğitim hastanesinde kesitsel araştırma yapıldı. Kayıllı tüm diş hekimliği araştırma görevlileri çalıșmaya katılmaya davet edildi. Veri toplama, kendi kendine yönetilen ve doğrulanan anket aracılığıyla gerçekleștirildi. Nihai veriler, SPSS sürüm 21.0 (IBM, Armonk, NY, ABD) kullanılarak analiz edildi. Frekanslar ve yüzdeler gibi tanımlayıcı istatistikler belirlendi.

Bulgular: Anket, davet edilen katılımcılar tarafından\% 92,5 yanıt oranıyla dolduruldu. Erkeklerin ( $n=30, \% 60)$ yaş ortalaması kadınların ( $\mathrm{n}=20$, \%40) yaş ortalamasından 27,44 (SS $\pm 2,32$ ) fazlaydı. Son 1 yılda katılımcların hiçbiri farmakovijilans eğitimi almamıştı. Katılımcıların çoğu (\% 60) farmakovijilansı tanımlayamadı ve diş hekimlerinin yalnızca \%20’si ( $\mathrm{n}=10)$ ADR'leri doğru șekilde tanımladı. Ankete katılanların çoğu (\% 90) ADR raporlamasını profesyonel bir zorunluluk olarak kabul ediyor ve yüzde altmıș $(n=30)$ ciddi ve beklenmedik ADR’lerin bildirilmesinin zorunlu olduğunu algıladı. Katılımcılar, ADR formlarının eksik raporlanmasının ana nedeninin ADR formlarının doldurulması sırasında yaşanan zorluklar, zamanlama kaybı ve farmakovijilans konusunda bilgi eksikliğinden kaynaklandığını fark ettiler. Ayrıca tüm diş hekimleri muayenehaneleri sırasında ciddi/şiddetli ADR gözlemlemediklerini belirtti ve \% 40’ı $(n=20)$ bir hastayla ilk kez iletişimde bulunurken ADR öyküsü sormadığını bildirdi. Katılımcıların farmakovijilans ve advers ilaç reaksiyonlarına karşı zayıf bilgi tutumu ve uygulaması vardı ( $\mathrm{p}$ değeri $<0,05$ ).

Sonuç: Bu çalışma, diş hekimliği araştırma asistanları arasında farmakovijilans ve ADR konusunda farkındalık ve bilgi eksikliği olduğunu göstermiştir. Eğitim programına farmakovijilans literatürünün dahil edilmesi zorunludur ve akılcı uygulamalar için diş hekimlerine mezuniyet öncesi ve sonrası eğitim verilmelidir.

Anahtar Kelimeler: Farmakovijilans, advers ilaç reaksiyonları, diş hekimleri, bilgi, Türkiye, hastane

Corresponding Author/Sorumlu Yazar: Zakir Khan, Tip Fakültesi, Tibbi Farmakoloji Anabilim Dalı, Çukurova Üniversitesi, 01330, Sarıçam, Adana, Türkiye (Önceki Kurumu: Department of Pharmacy, Quaid-i-Azam University, Islamabad, Pakistan)

E-mail/E-posta: zakirkhan300@gmail.com, zakirkhan@bs.qau.edu.pk

Received/Geliş: 15.04 .2020 Accepted/Kabul: 24.05 .2020 


\section{INTRODUCTION}

The World Health Organization (WHO) define an adverse drug reaction (ADR) as "a hazardous and unintended effect occurs at normal doses used for prophylaxis, diagnosis or treatment in humans for the modification of physiological function" (1) adverse drug reactions are among the main causes of illness, death and higher economic burden in health systems worldwide (2). ADRs are estimated to cause $3 \%$ of all deaths in the general population and up to $5 \%$ of all deaths in hospitalized patients (3). Despite all the benefits of pharmacotherapy, ADRs are known to pose a risk to drug therapy. In preclinical studies, the substance was found to be positive in terms of efficacy and safety in humans placed on the market after the new drug application process. Although these drugs are questioned for ADRs during clinical drug research and some ADRs are identified in the short product information for any drug. However, these data may not be sufficient and, for this reason, safety data must be collected in real life after the drug has been released. Knowledge of pharmacovigilance is crucial for the timely identification of ADRs. According to WHO, pharmacovigilance consists of activities to identify, evaluate, understand and prevent ADRs and other drug-related problems (1).

The Uppsala Monitoring Center (UMC), a WHO collaborating center, was founded in 1978 and continuously monitors ADRs reported from collaborative countries and plays a vital role in decision-making for national pharmacovigilance authorities. Turkey started the pharmacovigilance program under the name of the "Turkish Pharmacovigilance Center" (TUFAM) in 2005. ADR reports may be forwarded by health care professionals (HCPs) to TUFAM either directly or through the pharmacovigilance contact person (PCP) $(2,4)$. Spontaneous reporting plays an important role in the detection of unsuspected, serious and unusual ADRs previously undetected during different phases of the clinical trial. However, reporting remains a major challenge and highlighted in the previously published studies $(2,4-6)$.

Prescriber is a core member of the healthcare team, supplying information relevant to suspicious ADRs is the prescriber's moral obligation and an essential component of pharmacovigilance and improved patient care practices (4). Many factors related to knowledge, attitudes, and practices are responsible for under-reporting of ADRs by prescribers and relate to ignorance, lack of awareness, training, supporting staff and time $(2,4,6)$. Various studies have been conducted to assess knowledge and attitudes towards pharmacovigilance and ADR reporting among medical professionals (4-9). However, there are limited data available, particularly among dental professionals in Turkey, and no studies conducted previously in our setting. Dental doctors are also involved in the prescription of many therapeutic interventions, including allopathic medicines such as local anesthetics, antibiotics, analgesics and antiinflammatory drugs $(6,10)$. Antibiotics and analgesics are among the major causes of ADRs $(6,11)$.

Consequently, the possibility of ADRs in dentistry cannot be overlooked and it is important to consider the experience and attitude of a very particular group of prescribers. The aim of this study was therefore to assess pharmacovigilance and adverse drug reactions knowledge, attitudes and practices of research assistants working at the public sector university dental hospital in Turkey and, if possible, to suggest ways to enhance good pharmacovigilance activities based on findings.

\section{MATERIAL AND METHOD}

A cross-sectional survey was conducted in a teaching hospital at Cukurova University, Adana, Turkey, for one month. All the registered dental research assistants were invited to participate in the study. This study was approved by the university /local human research ethics committee and all procedures performed in studies involving human participants were in accordance with the ethical standards of the institutional and/or national research committee and with the 1964 Helsinki declaration and its later amendments or comparable ethical standards. The study was carried out with the permission of Çukurova University's Institutional Review Boards and Çukurova University School of Medicine Non-Interventional Clinical Research Ethics Committee (Meeting number: 86, Decision number: 114, Date of approval: 08 March 2019).

The dental research assistant is a person who assists the dentist in the entire treatment process, including operations. Informed written consent was also obtained from the study participants. Pharmacists, nurses, and paramedics working in dental hospital were under exclusion criteria. A pre-validated survey questionnaire was design for this study. Several strategies concerning the professional appearance of the questionnaire, the easy language, the conciseness, the good balance between content and length, and prescribers had dedicated time to read and complete the questionnaire were adopted to improve the response rate. The available literature has been systematically reviewed by investigators. Relevant published studies $(4-6,12,13)$ were evaluated for the design of a questionnaire. Content and face validity of the questionnaire have been carried out. Two academic experts evaluated the contents of the questionnaire for validation purposes. The final recommended amendments have been included in the questionnaire. The final questionnaire consisted of four parts; first, covering basic demographic characteristics of the participants such as age, gender, work experience, and pharmacovigilance training in the last one year. Second, the assessment of participants "knowledge included seven questions (three open-ended and four closed-ended questions). Third, evaluate the attitude of 
the respondents to close-ended questions. The fourth part included questions to evaluate their practices.

\section{Statistics}

The final data was analyzed by using SPSS version 21.0 (IBM, Armonk, NY, USA). Descriptive statistics such as frequencies and percentages have been determined. Chi-Square tests were applied to determine the nature of correlation among knowledge, attitude, and practice sections. A p-value of less than 0.05 was considered as a level of significance.

\section{RESULTS}

A total of 54 research assistants are enrolled and worked in a selected setting according to the data given by the teaching hospital. The questionnaire was completed by 50 participants with a response rate of $92.5 \%$. Male $(n=30$, $60 \%)$ was more than female $(n=20,40 \%)$. The average age of respondents was 27.44 (standard deviation of \pm 2.32 ) years. The participants were found to be a dentist for an average of 4.5 years. In the last year, none of the participants received pharmacovigilance training. The results obtained on the question of the definition of pharmacovigilance show that the majority of participants $(60 \%)$ were unable to define pharmacovigilance. Only 20\% $(n=10)$ of the dentists have correctly defined ADRs. Moreover, no one could answer the question "Can you write the TUFAM expansion?" (Table). Approximately $40 \%$ of the respondents reported that they had encountered with ADR. Surprisingly, however, all participants have poor knowledge and have also not previously learned about filling out the ADR notification form. All respondents expect that herbal medicines are also responsible to cause ADRs. The majority of respondents $(90 \%)$ recognize ADR reporting as a professional obligation. Sixty percent $(n=30)$ of the participants felt that the reporting of serious and unexpected ADRs are mandatory. All respondents $(n=50)$ also reported that ADRs can be a responsible cause of death and proper reporting of ADRs is crucial to improved patient safety. Half of the participants $(n=25)$ believe that filling of ADR notification forms causes difficulties and loss of time in the working environment. All dentists perceived the lack of information on pharmacovigilance as the main reason for under-reporting of ADRs and the availability of ADR forms in an accessible collection box in all clinical departments would be helpful for better practices. On the other hand, the result shows that all dentists reported that they did not observe serious/severe ADRs, nor did they witness ADRs due to herbal products during their practice. Questioning about the past and current history of the drug is an important part of the medical treatment process. However, $40 \%(n=20)$ of dentists reported not asking about drug history while interacting with a patient for the first time. The participants had poor knowledge attitude and practice towards the pharmacovigilance and adverse drug reactions ( $\mathrm{P}$ value $<0.05)$ (Table).

\begin{tabular}{|c|c|c|c|}
\hline Variables & Response n (\%) & Response n (\%) & Chi-square test \\
\hline Knowledge questions (open-ended) & Correct & Wrong & P-Value ${ }^{\star}$ \\
\hline 1. Can you please describe the pharmacovigilance? & $20(40)$ & $30(60)$ & $<0.05$ \\
\hline 2. Can you define an adverse drug reaction? & $10(20)$ & $40(80)$ & $<0.05$ \\
\hline 3. Can you write the extension of the TUFAM? & $0(0)$ & $50(100)$ & $<0.05$ \\
\hline Knowledge questions (close-ended) & Yes & No & \\
\hline 4. Have you ever had encountered any adverse drug reactions? & $2040)$ & $30(60)$ & $<0.05$ \\
\hline 5. Do you know how to fill out the notification form for an adverse drug reaction? & $0(0)$ & $50(100)$ & $<0.05$ \\
\hline 6. Have you learned to fill out an adverse drug notification form before that? & $0(0)$ & $50(100)$ & $<0.05$ \\
\hline 7. Can we expect adverse reactions to herbal medicines? & $50(100)$ & $0(0)$ & $<0.05$ \\
\hline Attitude questions (closed-ended) & Yes & No & \\
\hline 8. Is there a professional obligation to report an adverse drug reaction? & $45(90)$ & $5(10)$ & $<0.05$ \\
\hline $\begin{array}{l}\text { 9. Should it be reported when there are serious adverse reactions or unexpected } \\
\text { adverse reactions? }\end{array}$ & $30(60)$ & $20(40)$ & $<0.05$ \\
\hline 10. Do you think that adverse drug reactions can lead to death? & $50(100)$ & $0(0)$ & $<0.05$ \\
\hline $\begin{array}{l}\text { 11. Do you think that the safety of the patient will be improved by filling out the } \\
\text { adverse reaction reporting forms? }\end{array}$ & $50(100)$ & $0(0)$ & $<0.05$ \\
\hline $\begin{array}{l}\text { 12. Do you think that filling out the adverse reaction notification forms will cause } \\
\text { difficulties and loss of time in the working environment? }\end{array}$ & $25(50)$ & $25(50)$ & 1.000 \\
\hline $\begin{array}{l}\text { 13. Do you think that the lack of information on pharmacovigilance is the main } \\
\text { reason behind the under-reporting of ADRs }\end{array}$ & $50(100)$ & $0(0)$ & $<0.05$ \\
\hline $\begin{array}{l}\text { 14. Does it help that the adverse reaction reporting forms are in an accessible } \\
\text { collection box in all clinical departments? }\end{array}$ & $50(100)$ & $0(0)$ & $<0.05$ \\
\hline Practice questions (closed-ended) & Yes & No & \\
\hline $\begin{array}{l}\text { 15. Have you ever had an encounter with serious/severe adverse drug reactions } \\
\text { during practice? }\end{array}$ & $0(0)$ & $50(100)$ & $<0.05$ \\
\hline 16. If you have ever had an adverse drug reaction, have you reported it? & $0(0)$ & $50(100)$ & $<0.05$ \\
\hline 17. Have you ever seen an adverse reaction to herbal products? & $0(0)$ & $50(100)$ & $<0.05$ \\
\hline $\begin{array}{l}\text { 18. When taking a medical history, do you ask about an adverse drug reaction } \\
\text { while interacting with a patient for the first time? }\end{array}$ & $30(60)$ & $20(40)$ & $<0.05$ \\
\hline
\end{tabular}




\section{DISCUSSION}

ADRs are among the common causes of morbidity and mortality and impose a higher financial burden on health care systems. Awareness of pharmacovigilance and ADRs among health professionals can minimize the factors that contribute to ADR reporting. Knowledge is a very important factor that influences attitudes and practices. In the current study, the knowledge of the majority of participants was poor and the terms pharmacovigilance and ADRs were incorrectly defined. Similar findings have also been reported in previously published studies (4-6). This finding urges the need for continuing education and training (4). Establishing national pharmacovigilance centers and drug information points in all hospitals for patients and dentists is compulsory for continuous education and training.

Of all the respondents, about $40 \%$ had encountered with ADR. Surprisingly, however, all participants (100\%) stated that they did not know how to fill out the ADR reporting form and had not even learned about the procedure before. The studies conducted in the United Kingdom (74.6\%) (12) and India (27.5\%) (6) reported increased awareness about the ADRs reporting system among dental practitioners as compared to our study. Low awareness and malpractice related to pharmacovigilance in the current setting may be attributed to the poor TUFAM education campaigns (4). Therefore, increased awareness among dental practitioners about the reporting system of ADR is required through effective campaigning by health care authorities (6).

Most of the respondents (90\%) perceived ADR reporting as a professional obligation. These findings have been supported by a study in Malaysia (13). However, the study carried out in India (6) reported that more than $50 \%$ of the respondents did not realize ADR reporting as a professional obligation. Personal discussions and awareness-raising programs to change the attitudes of the dentist may be helpful to dispel misconceptions $(6,13)$.

Half (50\%) of the participants believed that filling of ADR form caused difficulties and time loss in the work environment. Additionally, the respondents also stated that the lack of information and training on pharmacovigilance are the main reasons for the underreporting of ADR. A similar finding has also been reported in previous studies $(6,13)$. Each year, TUFAM organizes one or two training sessions for PCPs and HCPs, including dentists, and also monitors their work in each health care institution. However, as stated by a previous study (4), the TUFAM did not systematically follow up on these activities.
All of the participants reported that they had not experienced a serious/severe ADR, had not reported it and nor witnessed an ADR due to herbal products in their practice. Moreover, about 40\% (40\%) of the dentist indicated that they did not ask about ADRs while taking a patient's medical history for the first time. Such findings are troubling and need immediate attention. Therefore, to enhance patient health care, continuous training modules on the subject of pharmacovigilance and activities such as highlighting the purpose and value of ADR reports are important (15).

According to the TUFAM Regulation, it is compulsory to include the literature on pharmacovigilance in the curricula of the educational program. Since there is no relevant global standard for teaching and training related to pharmacovigilance at the university level for medical, pharmacy, nursing and other paramedical undergraduate students in Turkey $(4,14,15)$. The recommendations suggested by the recently published study, which highlighted the program that focused on deliberate discussions on pharmaceutical care activities, including appropriate pre-and post-treatment counseling, periodic drug use and error prevention audits, drug discharge reviews, and ADR reporting, should be implemented in Turkey for better health outcomes (16).

There are some strengths and limitations to this study. No significant effort has been made to the best of our knowledge, focusing mainly on the assessment of knowledge attitude and practice among dental research assistants. Socio-cultural factors also have a significant impact that varies from country to country. First, it is not a representative sample of general practitioners, as we reported cross-sectional data from only one hospital. Second, the potential for bias on the part of respondents, such as any survey, where respondents choose to have a socially favorable opinion instead of real answers. Despite these limitations, our findings indicate significant implications and highlight sizeable pharmacovigilance activities in Turkey.

\section{CONCLUSION}

This study concluded that there was a lack of awareness and knowledge of pharmacovigilance and ADR among dental research assistants. The majority of the participants had poor knowledge attitude and practice towards the pharmacovigilance and adverse drug reactions. The participant perceived that a lack of information and training on pharmacovigilance are the main reasons for under-reporting ADRs. The inclusion of pharmacovigilance literature in the education program is mandatory and pre-and post-graduate training should be provided to dentists for better practices. Additionally, 
the close follow-up of pharmacovigilance activities and prescribing practices, the incorporation of the ADR reporting system into the electronic prescribing system and the timely feedback of TUFAM to dentists are effective interventions for improved knowledge, reporting rates and better pharmacovigilance system.

\section{ETHICAL DECLARATIONS}

Ethics Committee Approval: The study was carried out with the permission of Çukurova University's Institutional Review Boards and Çukurova University School of Medicine Non-Interventional Clinical Research Ethics Committee (Meeting number: 86, Decision number: 114, Date of approval: 08 March 2019).

Informed Consent: Written informed consent was obtained from all participants who participated in this study.

Referee Evaluation Process: Externally peer-reviewed.

Conflict of Interest Statement: The authors have no conflicts of interest to declare.

Financial Disclosure: The authors declared that this study has received no financial support.

Author Contributions: All of the authors declare that they have all participated in the design, execution, and analysis of the paper, and that they have approved the final version.

\section{REFERENCES}

1. International society of pharmacovigilance. 18th ISoP Annual Meeting "Pharmacovigilance without borders" Geneva, Switzerland, 11-14 November, 2018. Drug Safety 2018; 41: 1103273.

2. Özcan G, AykaçE, Kasap Y, Nemutlu NT, Sen E, Aydınkarahaliloğlu ND. Adverse drug reaction reporting pattern in Turkey: analysis of the national database in the context of the first pharmacovigilance legislation. Drugs-real world outcomes 2016; 3: 33-43.

3. Ithnin M, Rani MDM, Latif ZA, et al. Mobile app design, development and publication for adverse drug reaction assessments of causality, severity and preventability. JMIR Mhealth Uhealth 2017; 5: e78.

4. Güner MD, Ekmekci PE. Healthcare professionals' pharmacovigilance knowledge and adverse drug reaction reporting behavior and factors determining the reporting rates. J Drug Assess 2019; 8: 13-20.

5. Alshakka M, Bahattab OA, Ali $\mathrm{H}$, et al. Comparison of the knowledge and perception of pharmacovigilance among pharmacy, dental and medical students in Aden-Yemen. J Pharm Pract Community Med 2017; 3: 254-61.

6. Khan SA, Goyal C, Tonpay SD. A study of knowledge, attitudes, and practice of dental doctors about adverse drug reaction reporting in a teaching hospital in India. Perspect Clin Res 2015; 6: 144-9.

7. Sivadasan S, Sellappan M. A study on the awareness and attitude towards pharmacovigilance and adverse drug reaction reporting among nursing students in a private university, Malaysia. Int J Current Pharm Res 2015; 7: 84-9.
8. Farha RA, Alsous M, Elayeh E, Hattab D. A cross-sectional study on knowledge and perceptions of pharmacovigilance among pharmacy students of selected tertiary institutions in Jordan. Trop J Pharm Res 2015; 14: 1899-905.

9. Khan MU, Ahmad A, Ejaz A, et al. Comparison of the knowledge, attitudes, and perception of barriers regarding adverse drug reaction reporting between pharmacy and medical students in Pakistan. J Educ Eval Health Prof 2015; 12: 28.

10. Howard RL, Avery AJ, Slavenburg S, et al. Which drugs cause preventable admissions to hospital? A systematic review. Br J Clin Pharmacol 2007; 63: 136-47.

11. Mersha AG. Attitude and perception of medical interns about antimicrobial resistance: a multi-center cross-sectional study in Ethiopia. Antimicrob Resist Infect Control 2018; 7: 149.

12. Yip J, Radford DR, Brown D. How do UK dentists deal with adverse drug reaction reporting? Br Dent J 2013; 214: e22.

13.Shalini S, Mohan S. Knowledge and attitude towards pharmacovigilance and adverse drug reaction reporting among dental students in a private university, Malaysia. J Young Pharm 2015; 7: 118-25.

14.Ergün Y, Ergün TB, Toker E, Ünal E, Akben M. Knowledge attitude and practice of Turkish health professionals towards pharmacovigilance in a university hospital. Int Health 2019; 11: 177-84. doi:10.1093/inthealth/ihy073.

15. Karataş Y, Pelit A. Yeni çıkan ilaçların güvenlik (farmakovijilans) açısından izlenmesinin önemi [Translate: Importance of monitoring new drugs in terms of security (pharmacovigilance)]. Arşiv Kaynak Tarama Derg 2018; 27: 500-6.

16. Sharma S, Khanal T, Shrestha S, Adhikari B. A celebration of world pharmacist day 2018 focusing to strengthen the pharmacy services at an oncology-based hospital in Nepal: Inspiration for others in developing countries. Res Social Adm Pharm 2019; 15: $117-8$. 